\title{
Effect of Moisture Content on Selected Physical and Mechanical Properties of Two Varieties of Tigernut (Cyperus spp)
}

\author{
A. S. Oyerinde ${ }^{1} \&$ A. P. Olalusi ${ }^{2}$ \\ ${ }^{1}$ Biosystems Engineering Department, Auburn University, Alabama, USA \\ ${ }^{2}$ Department of Agricultural Engineering, Federal University of Technology, Akure, Nigeria \\ Correspondence: A. S. Oyerinde, Biosystems Engineering Department, Auburn University, Alabama, USA. \\ E-mail: asoyerinde@gmail.com
}

\author{
Received: July 22, 2013 Accepted: September 10, 2013 Online Published: September 26, 2013 \\ doi:10.5539/jfr.v2n6p24 URL: http://dx.doi.org/10.5539/jfr.v2n6p24
}

\begin{abstract}
The effect of moisture content on some physical and mechanical properties of two varieties of tigernuts (Cyperus esculentus) was investigated. These properties include: geometric dimensions, linear dimensions, 1000 tuber weight, bulk density, tuber size, sphericity, angle of repose, porosity, coefficient of static friction and compressive strength. The moisture content levels used were 20, 25, 30, 35 and 40\% wet basis (wb), and the two tigernut varieties used were yellow and brown types. The linear dimension, geometric diameter, sphericity, 1000tuber weight, bulk density and angle of repose in both varieties increased with increasing moisture content. The average length, width and thickness of the yellow variety increases more than the brown variety at the determined moisture contents. True density of the yellow variety increased while the brown variety decreased with increase in moisture content. The porosity of the yellow variety reduces with increase in moisture content from 45.95 at $20 \% \mathrm{mc}$ to 42.4 at $40 \% \mathrm{mc}$, while the brown variety decreased from 42.72 at $20 \%$ mc to 30.77 at $40 \%$ moisture content. The yellow variety had bigger size tubers than the brown variety and this has serious implications in packing, handling and transportation issues.
\end{abstract}

Keywords: moisture content, physical properties, tigernut, mechanical properties

\section{Introduction}

Tigernut (Cyperus esculentus) is an underutilized crop of the family Cyperaceae which produces rhizomes from the base and tubers that are somewhat spherical. It is a root crop which grows widely in wet places as a grass and is sometimes cultivated for its small and sweet tubers (Eteshola \& Oraedu, 1996). Other common names of tiger nut are; earth almond, chufa, yellow nut sedge and Zulu nuts (Ekeanyanwu \& Ononogbu, 2010).

Tigernut grows mainly in the middle belt and northern regions of Nigeria, it is known in Nigeria as 'Ayaya' in Hausa, 'Imumu' in Yoruba and 'Akiausa' in Igbo where three varieties (black, brown and yellow) are cultivated (Osagie \& Eka, 1998). Among these, only two varieties, yellow and brown are readily available in the market. The yellow variety is preferred over others because of its inherent properties like its large size, attractive colour and fleshier nature. The yellow variety also yields more milk, contains lower fat and higher protein and less anti-nutritional factors especially polyphenols (Okafor et al., 2003; Belewu \& Abodunrin, 2005; Ebringa, 2007).

In Nigeria markets, tigernuts are available in both fresh and dried forms. It's cultivation requires sandy soil and a mild climate. The tubers are planted between April and May and must be continuously irrigated until they are harvested in November and December. The tubers have to be properly dried before storage as the dried tubers possesses lesser weight. The tubers are regarded as a digestive tonic, having a heating and drying effect on the digestive system and enhances urine production (Galedar et al., 2010). The tubers are said to be aphrodisiac, possesses stimulating effect and are also used in the treatment of flatulence, indigestion, colic, diarrhea, dysentery, debility and excessive thirst (Chevallier, 1996).

The tubers contain up to $30 \%$ of non-drying oil which is used in cooking, soap making, starch and flour preparation (Carruthers, 1986; Shaker et al., 2009; Muhammad et al., 2011). The selected properties (geometric dimensions, linear dimensions, 100th tuber weight, bulk density, tuber size, sphericity, angle of repose, porosity, coefficient of static friction and compressive strength) are important in many problems associated with the design of machines and the analysis of the behavior of the product during agricultural process operations such as 
handling, planting, harvesting, threshing, cleaning, sorting and drying. Solutions to problems in these processes involve knowledge of their physical and engineering properties (Irtwange, 2000; Varnamkhasti et al., 2008; Tavakoli et al., 2009). This study examined the effect of moisture content on the physical and mechanical properties of two varieties of tigernut (yellow and brown) that are useful in the design of harvesting and handling equipment.

\section{Materials and Methods}

\subsection{Sample Preparation}

The yellow and brown varieties of tigernut used for this study was obtained at a local market in Akure, Nigeria. The tubers were cleaned manually to remove all foreign matter such as dirt, stones, immature and broken seeds. The initial moisture content of the samples was determined by oven drying method at $103{ }^{\circ} \mathrm{C}$ for 48 hours as used by Sacilik et al., (2003). Selected samples were moistened with a calculated quantity of distilled water and conditioned to raise their moisture content to the desired different levels. Equation (1) was used to calculate the quantity of distilled water used according to Coskun et al. (2006).

$$
Q=w_{i}\left(\frac{m_{f}-m_{i}}{100-m_{f}}\right)
$$

Where $Q=$ mass of added water $(\mathrm{kg})$,

$\mathrm{w}_{i}$ is the initial mass of the sample $(\mathrm{kg})$,

$\mathrm{m}_{i}$ is the initial moisture content of the sample $(\%, d . b$.$) and$

$\mathrm{m}_{f}$ is the final moisture content of the sample $(\%, d . b$.$) .$

Five levels of moisture contents were obtained for both varieties, 20, 25, 30, 35 and $40 \%$ (wb). The samples were then stored in an airtight polythene and kept at $5{ }^{\circ} \mathrm{C}$ in a refrigerator for a week to achieve uniform moisture distribution within the sample.

\subsection{Linear Dimensions, Sphericity and 1000 Tuber Weight}

Average size was determined using 100 tubers that were randomly picked from each of the five conditioned samples. Three linear dimensions of the tubers namely; length $L$, width $W$ and thickness $T$ were measured with digital vernier caliper with accuracy of $0.001 \mathrm{~mm}$ and their equivalent diameter $\left(D_{g}\right)$ determined obtained using Equation (2) by Sreenarayanan et al. (1985).

$$
D_{g}=(L W T)^{0.333}
$$

The sphericity of the tubers was calculated according to Mohsenin, 1978 as shown in Equation (3).

$$
\phi=\frac{(L W T)^{0.333}}{L}
$$

Where $L=$ length (mm)

$$
\begin{aligned}
& W=\text { width and }(\mathrm{mm}) \\
& T=\text { thickness }(\mathrm{mm})
\end{aligned}
$$

One thousand tuber weight $\left(\mathrm{W}_{1000}\right)$ was determined using the method described by Baryeh (2002). The 100 seeds were weighed with the aid of an electronic balance and multiplied by 10 to give the mass of 1000 seeds.

\subsection{Density, Porosity and Angle of Repose Determination}

The true density and volume were determined using the toluene displacement method. Toluene was used in place of water because it is not easily absorbed by the seeds. The volume of toluene displaced was found by immersing a weighed quantity of tigernuts in toluene (Singh \& Goswami, 1996). Bulk density was calculated from the mass of bulk tigernuts tubers divided by the volume of the container (Garnayak et al., 2008). The porosity, of the tubers was calculated from the values of the bulk and true densities obtained using Equation (4) by Mohsenin, (1970). 


$$
\varepsilon=\frac{\left\lfloor\left(\rho_{g}-\rho_{b}\right) 100\right\rfloor}{\rho_{g}}
$$

Where $\rho_{\mathrm{g}}=$ bulk density $\left(\mathrm{kg} \mathrm{m}^{-3}\right)$

$$
\rho_{\mathrm{b}}=\text { true or particle density }\left(\mathrm{kg} \mathrm{m}^{-3}\right)
$$

The static angle of repose is the angle with the horizontal at which the material will stand when piled. This was determined through the use of the apparatus consisting of a plywood box of two plates fixed and adjustable. The box was filled with the sample, and then the adjustable plate was inclined gradually allowing the seeds to flow and assume a natural slope (Tabatabeefar, 2003; Varnamkhasti et al., 2008; Tavakoli et al., 2009).

\subsection{Coefficient of Static Friction Determination}

The coefficients of static friction were determined on three structural surfaces namely: galvanized steel, glass, stainless steel. The static coefficient of friction was determined using an inclined plane (Suthar \& Das, 1996). The friction surface was part of a special construction, which is hinged at one end so that it can be lifted gradually at the unhinged end using a screw device as used by Bart-Plange, and Baryeh (2003). The angle at which the tubers just began to slide down was recorded as the static angle of friction between the tubers and the friction surface. Baryeh (2001, 2002), Dutta et al. (1988), Joshi et al. (1993), Singh and Goswani (1996) and Suthar and Das (1996) used this method for other grains and seeds. The coefficient of friction was calculated using Equation (5) as:

Where $\mu=$ coefficient of friction and

$$
\mu=\tan \theta
$$

$\theta=$ angle of tilt in degrees.

\subsection{Compressive Strength}

The tests were conducted using a universal testing machine (UTM) controlled by a micro-computer where results, statistics and graphs were automatically generated. The breaking force at peak and the Young modulus for the tubers were determined.

\section{Results and Discussion}

\subsection{Effect of Moisture Content on Tigernut Dimensions}

Figure 1 shows the variations of average values of the length, width, thickness and geometric diameters of the two varieties of the tiger tubers with increasing moisture content. All the linear dimensions increased with increasing tuber moisture content for both varieties. This is probably due to the air voids trapped in the cell vacuoles as they absorb moisture and thereby making the tubers display appreciable dimension change. This indicates that when the moisture is increased, the tubers increase in length, width, thickness and geometric diameter within the moisture range of $20-40 \%(\mathrm{w} b)$ for yellow and brown varieties. The geometric dimension and their frequencies suggest that sieving will be a good method of separating the tubers from particles.

\subsection{Effect of Moisture Content on Sphericity}

The values of sphericity were calculated using Equation (3) by using the data on geometric mean diameter and the length of the tigernuts and the results obtained are presented in Figure 2. These figures indicate that the sphericity increased with increasing moisture content in both varieties from 0.86 to 0.89 for the yellow and 0.91 to 0.94 for the brown type.

\subsection{Effect of Moisture Content on Mass of Tigernuts}

Figure 3 shows the variation of tuber mass with moisture content. The tuber mass increased linearly from 0.32 to $0.42 \mathrm{~g}$ and 1.13 to $1.43 \mathrm{~g}$, respectively, for the yellow and brown varieties as the moisture content increases. The figure shows that the lower the moisture content the lower the tuber mass. Transportation of the tuber is therefore advisable at low moisture content because of the reduction in weight.

\subsection{Effect of Moisture Content on 1000-Tuber Mass}

The variation of 1000-tuber weight with moisture content for both varieties of tigernut is shown in Figure 4 . The figures show that the tuber mass increased with tuber moisture content. The variation can be expressed mathematically as $\mathrm{W}_{1000}=1.28 m c+87.8$ with a correlation coefficient, $\mathrm{R}^{2}$ of 0.87 in the yellow variety and $\mathrm{W}_{1000}=$ $0.52 m c+20.4$ with a correlation coefficient, $R^{2}$ of 0.91 in the brown variety. The 1000 -tuber mass ranged from $113 \mathrm{~g}$ to $143 \mathrm{~g}$ in the yellow variety and $32 \mathrm{~g}$ to $42 \mathrm{~g}$ in the brown variety for the sampled moisture content. The result showed that there were significant differences between the mean values of the 1000-tuber weight of the 
tigernuts at the $1 \%$ probability. Similar patterns have been reported for guna seeds, soyabean, cocoa beans, cumin seeds and bambara groundnuts (Aviara et al., 1999; Baryeh, 2001; Deahpande et al, 1993; Bart-Plange \& Baryeh, 2003; Singh \& Goswani, 1996; Visvanathan et al., 1996). The weights indicate that blowers can be used to transport the tubers in a processing plant.

\subsection{Effect of Moisture Content on Bulk Density}

The bulk density increased linearly with increasing moisture content from 590 to $630 \mathrm{~kg} \mathrm{~m}^{-3}$ in the yellow variety and from 600 to $640 \mathrm{~kg} \mathrm{~m}^{-3}$ in the brown variety as show in Figure 5. The bulk density increases in both varieties were very close to each other. The increase in bulk density was due to an increase in mass due to moisture gain in the sample which was higher than the volumetric expansion of the bulk (Pradhan et al., 2008). A similar increasing trend in bulk density has been reported by Baryeh and Mangope (2002) for QP- 38 variety pigeon pea and Kingsley et al. (2006) for dried pomegranate seeds and Nikoobin et al. (2009) for chickpea seeds.

\subsection{Effect of Moisture Content on True Density}

The change in true density with moisture content for both varieties of tigernut is shown in Figure 5. Here, the density of the yellow type increases in a non-linear manner starting from $1260 \mathrm{~kg} \mathrm{~m}^{-3}$ to $1370 \mathrm{~kg} \mathrm{~m}^{-3}$ as the moisture content increases while the brown type decreases also in a non-linear manner from $1030 \mathrm{~kg} \mathrm{~m}^{-3}$ to 910 $\mathrm{kg} \mathrm{m}^{-3}$ as the moisture content increases from $20 \%$ to $40 \%$. The variation in tuber density may be due to a low decrease in mass of the tuber as well as the smaller sizes of the brown variety compared to its volumetric decrease as tuber moisture content decreases. These results suggest that the tubers are likely to have high terminal velocities because of their densities, making pneumatic separation from lighter particles very feasible.

\subsection{Effect of Moisture Content on Porosity}

Porosity of materials usually is dependent on the bulk as well on true densities, therefore the magnitude of the varieties were calculated using the data on the bulk and true densities using Equation 4 and the results are presented in Figure 6 . The porosity of the yellow variety reduces from $45.9 \%$ to $42.4 \%$ while that of the brown type reduces from $42.7 \%$ to $30.8 \%$ as the moisture content increases from $20 \%$ to $40 \%$. This has to do with the changes in the mass and density values of the sample as it absorbs more water. High porosity at low moisture content indicates that high numbers of tubers can be stored at low moisture content than at high moisture content due to an increase in the cohesion of the cell structure of the tigernuts as the moisture content increases.

\subsection{Effect of Moisture Content on Angle of Repose}

Figure 7 shows the effect of moisture increase on the angle of repose for the tigernut varieties. The values were found to increase from $20.3^{\circ}$ to $23.7^{\circ}$ and $21.3^{\circ}$ to $24.3^{\circ}$ respectively, for the yellow and brown varieties at the moisture range of $20 \%$ to $40 \%$. This increasing trend of angle of repose with moisture content occurs because surface layer of moisture surrounding the particle hold the tigernuts together by the surface tension (Prashan et al., 2008). These results were similar to those reported by Aluntas and Yildiz (2007) and Garnayak et al. (2008) for faba bean grains and jatropha seed, respectively.

\subsection{Effect of Moisture Content on Static Coefficient of Friction}

The variation of the coefficient of static friction with moisture content for the 2 varieties is shown in Figure 8 for three structural surfaces. At all moisture content levels, the static coefficient of friction was the highest for both varieties on galvanized steel and the least for stainless steel. The least value of static coefficient of friction may be due to smoother and more polished surface of the stainless steel than the other materials used. The reason for the increased friction coefficient at higher moisture content may be due to the water present in the tigernut tubers, offering a cohesive force on the surface of contact. As the moisture content of grains increases, the surface of the samples becomes stickier. Water tends to adhere to surfaces and the water on the moist tuber surface would be attracted to the surface across which the sample is being moved. Other researchers found that as the moisture content increased, the static coefficient of friction increased also (Baryeh \& Mangope, 2002; Altunta \& Yildiz, 2007; Pradhan et al., 2008). Knowledge of coefficient of friction of agricultural materials on various surfaces has long been recognized by engineers concerned with rational design of grain bins and other storage structures in grain handling (Varnamkhasti et al., 2008; Tavakoli et al., 2009).

\subsection{Compressive Strength}

The breaking force at peak and the Young modulus for the yellow variety were lower and reduces with increase in moisture content while the brown variety had a slightly higher values which increases at low moisture and then reduces as the moisture increases. Force at peak for the yellow variety reduces from $124.8 \mathrm{~N}$ at $20 \%$ moisture to $88.1 \mathrm{~N}$ at $40 \%$ moisture while it was $142.7 \mathrm{~N}$ and 167.3 for the same moisture range for the brown 
variety. The Young modulus values for the yellow variety reduces from $313.7 \mathrm{~N} \mathrm{~mm}^{-1}$ at $20 \%$ moisture to 224.7 $\mathrm{Nmm}^{-1}$ at $40 \%$ moisture while for the brown type it increase at low moisture $\left(847.7 \mathrm{~N} \mathrm{~mm}^{-1}\right.$ and $\left.20 \%\right)$ and then increase as the moisture level increases $\left(852.4 \mathrm{~N} \mathrm{~mm}^{-1}\right.$ and $\left.40 \%\right)$.

a

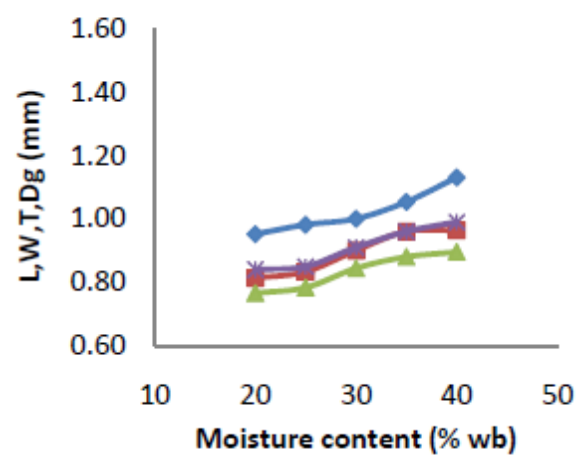

b

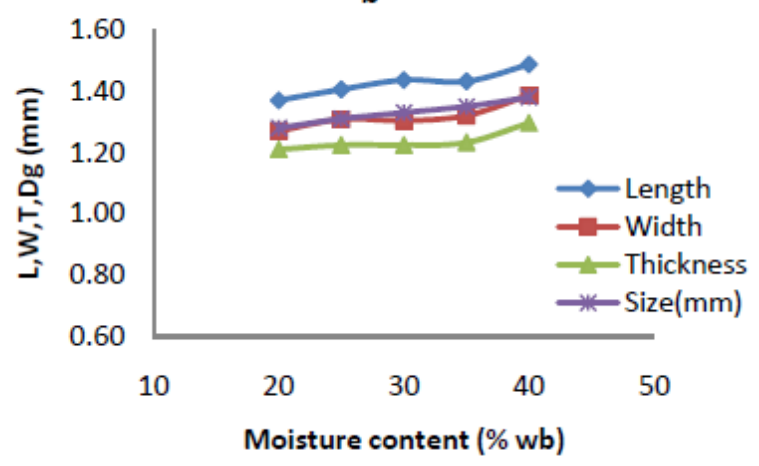

Figure 1. Linear dimensions against moisture content of the yellow (a) and brown (b) varieties of tigernut

a

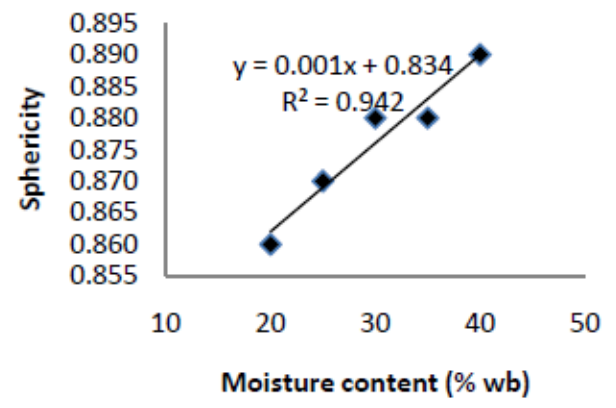

b

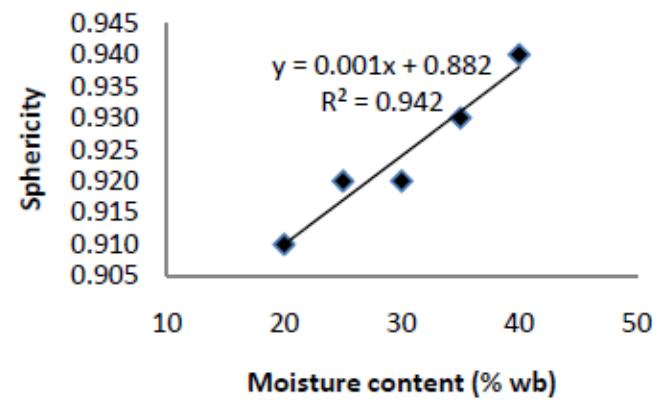

Figure 2. Sphericity against moisture content at different moisture levels of the yellow (a) and brown (b) varieties of tigernut

a

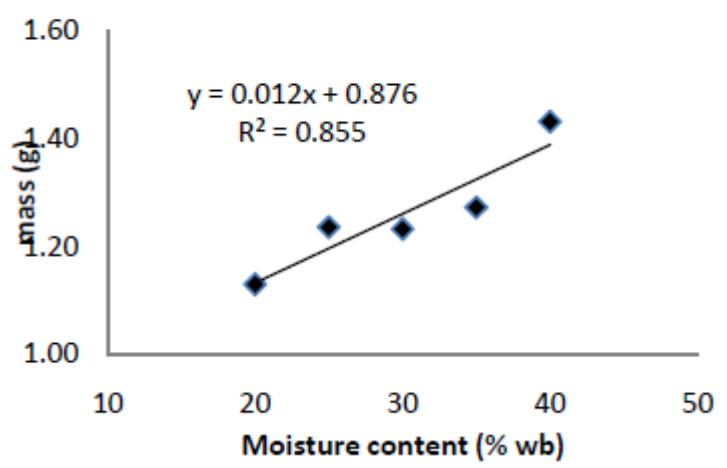

b

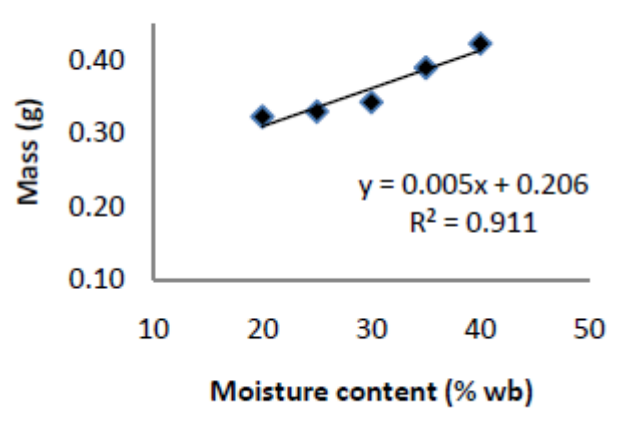

Figure 3. Mass of tuber against moisture content at different moisture levels of the yellow (a) and brown (b) varieties of tigernut 
a

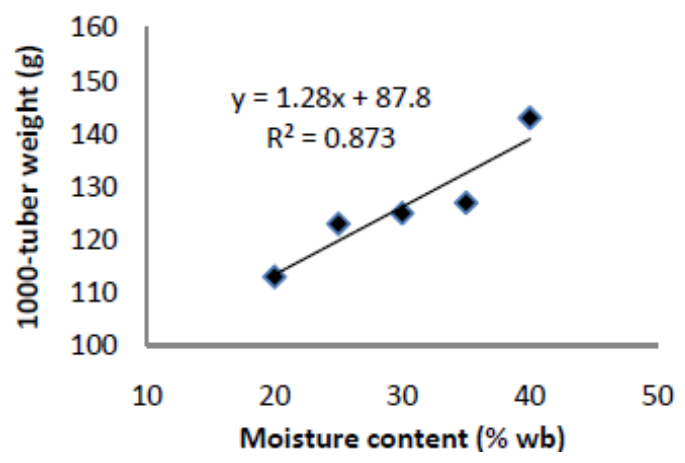

b

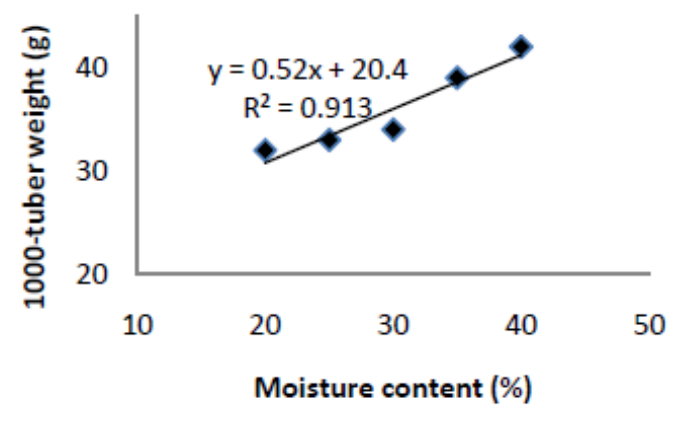

Figure 4. 1000- tuber weight against moisture content at different moisture levels of the yellow (a) and brown (b) varieties of tigernut

a

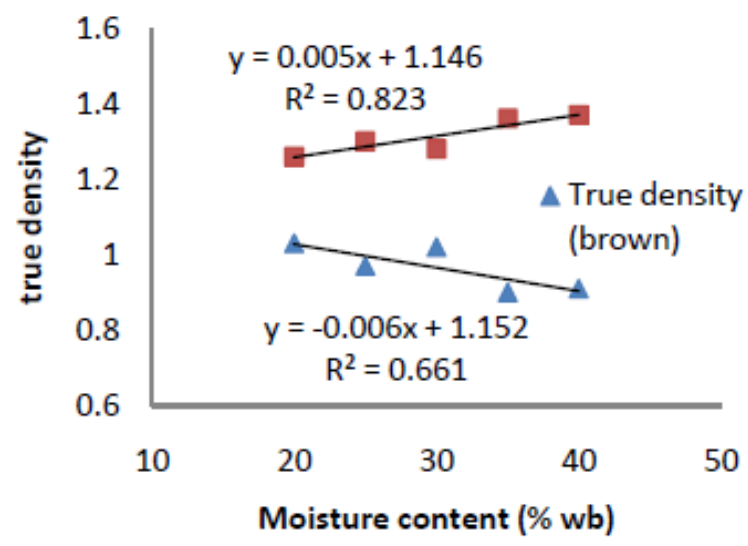

b

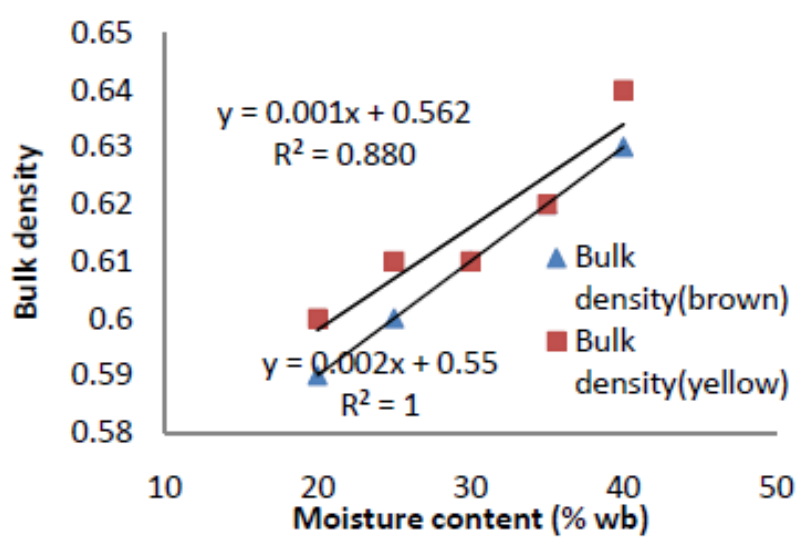

Figure 5. True density and bulk density variations with moisture content at different moisture levels levels of the yellow (a) and brown (b) varieties of tigernut

a

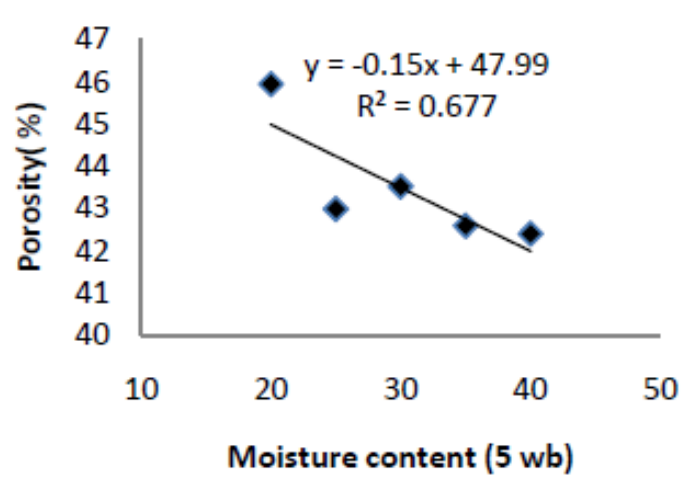

b

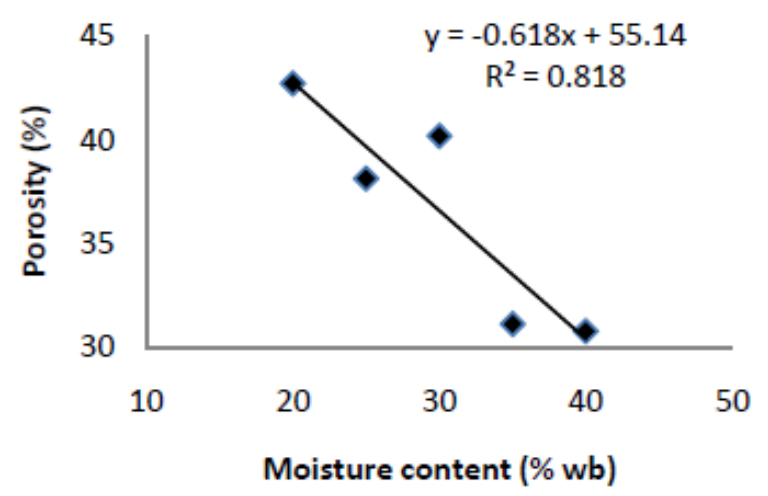

Figure 6. Porosity against moisture content at different moisture levels of the yellow (a) and brown (b) varieties of tigernut 
a

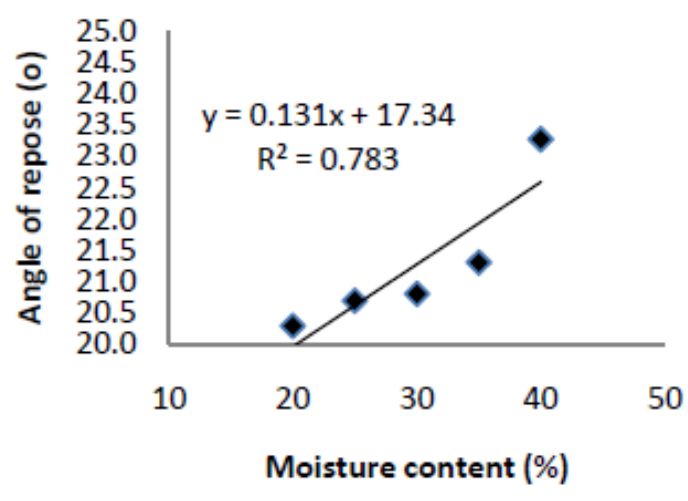

b

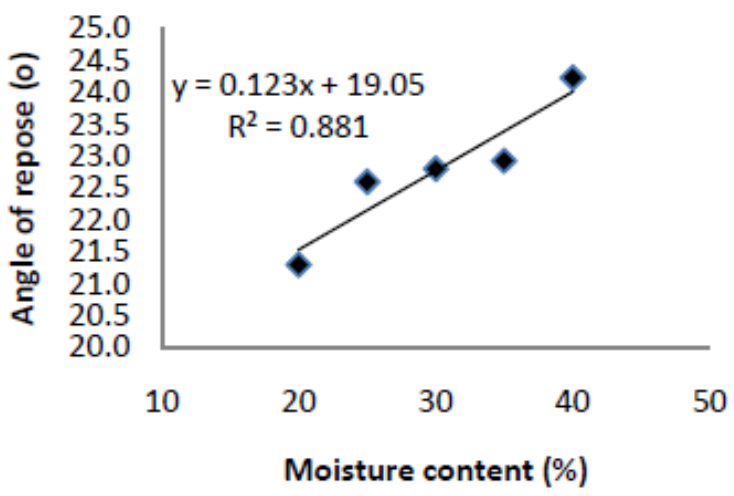

Figure 7. Angle of repose against moisture content at different moisture levels of the yellow (a) and brown (b) varieties of tigernut

a

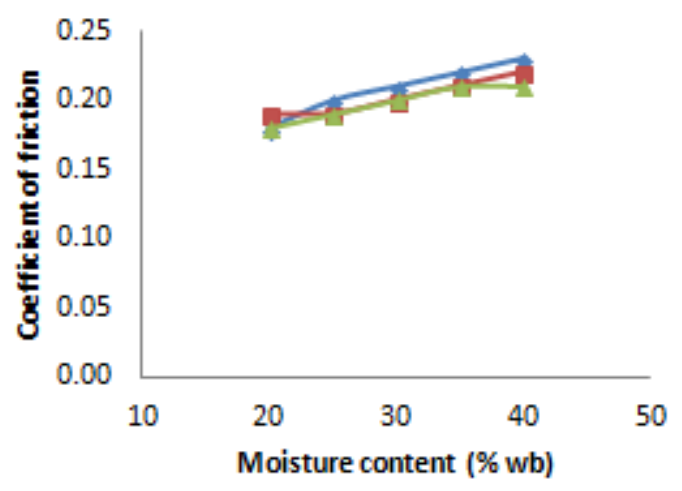

b

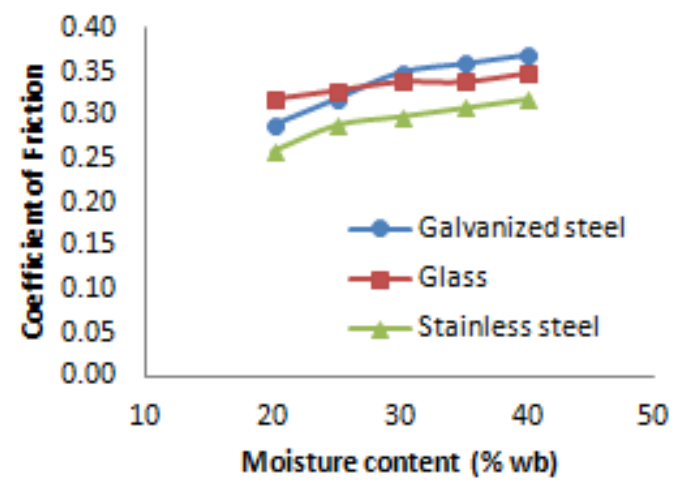

Figure 8. Coefficient of friction on different surfaces against moisture content at different moisture levels of the yellow (a) and brown (b) varieties of tigernut

\section{Conclusions}

The following conclusions are drawn from the investigations on selected physical and mechanical properties of two varieties of tigernuts (cyperus spp.) at five different moisture content levels. Physical and mechanical properties of tigernuts are dependent on their moisture contents. All the linear dimensions increased with increased moisture content for both varieties. The average length, width, thickness, geometric mean diameter, sphericity, volume, bulk density, thousand weight, tuber mass and angle of repose also increased. As the moisture increase in the samples, the porosity values reduce while bulk density increases. True density of the yellow variety increase significantly while the brown variety reduces with increase in moisture of the samples. The variation of the coefficient of static friction for three structural surfaces (glass, galvanized steel and stainless steel) at different moisture levels suggests the flow function of the samples on the materials of construction of the handling equipment. At all moisture content levels examined, the static coefficient of friction was the highest for both varieties on galvanized steel and the least for stainless steel. The least static coefficient of friction may be due to smoother and more polished surface of the stainless steel than the other materials used.

\section{References}

Altuntas, E., \& Yildiz, M. (2007). Effect of moisture content on some physical and mechanical properties of faba bean (Vicia faba L.) grains. J. Food Eng., 78, 174-183. http://dx.doi.org/10.1016/j.jfoodeng.2005.09.013

Aviara, N. A., Gwandzung, M. I., \& Hague, M. A. M. (1999). Physical properties of guna seeds. J. Agr. Eng. Res., 73, 105-111. http://dx.doi.org/10.1006/jaer.1998.0374 
Bart-Plange, A., \& Baryeh, E. A. (2003). The physical properties of Category B cocoa beans. Journal of Food Engineering, 60(3), 219-227. http://dx.doi.org/10.1016/S0260-8774(02)00452-1

Baryeh, E. A. (2001). Physical properties of bambara groundnuts. J. Food Eng., 47, 321-326. http://dx.doi.org/10.1016/S0260-8774(00)00136-9

Baryeh, E. A. (2002). Physical properties of millet. J. Food Eng., 51(1), 39-46. http://dx.doi.org/10.1016/S0260-8774(01)00035-8

Baryeh, E. A., \& Mangope, B. K. (2002). Some physical properties of QP-38 variety pigeon pea. J. Food Eng., 56, 59-65. http://dx.doi.org/10.1016/S0260-8774(02)00148-6

Belewu, M. A., \& Abodurin, O. A. (2005). Preparation of Kunnu from Unexploited Rich Food Source: Tiger nut (Cyperus esculentus). Pakistan Journal of Nutrition, 7(1), 109-111. http://dx.doi.org/10.3923/pjn.2008.109.111

Carruthers, S. P. (1986). Alternative Enterprises for Agriculture in the UK. Centre for Agricultural.

Chevallier, A. (1996). The Encyclopedia of Medicinal Plants. London: Dorling Kindersley Publishers.

Coskun, M. B., Yalçin, I., \& Özarslan, C. (2006). Physical properties of sweet corn seed (Zea mays saccharata Sturt.). J. Food Eng., 74(4), 523-528. http://dx.doi.org/10.1016/j.jfoodeng.2005.03.039

Deshpande, S. O., Bal, S., \& Ojha, T. P. (1993). Physical properties of soybean. J. Agric. Eng. Res., 56, 89-98. http://dx.doi.org/10.1006/jaer.1993.1063

Dutta, S. K., Nema, V. K., \& Bhardwaj, R. K. (1988). Physical properties of gram. J. Agric. Eng. Res., 39, 259-268. http://dx.doi.org/10.1016/0021-8634(88)90147-3

Ebringa, D. C. (2007). Proximate Compositions of Pea-nut, Tiger nut and walnut. In the Proceedings of NIFST 31st annual conference/AGM Abuja, Nigeria. pp. 169-170.

Ekeanyanwu, R. C., \& Ononogbu, C. I. (2010). Nutritive value of Nigerian tigernut (Cyperus esculentus L.). Agricultural Journal, 5, 297-302. http://dx.doi.org/10.3923/aj.2010.297.302

Eteshola, E., \& Oraedu, A. C. (1996). Fatty acid composition of tigernut tubers, baobab seeds (Adasonia digitata L.) and their mixture. Journal of American Oil Chemists Society, 73, 255-257. http://dx.doi.org/10.1007/BF02523905

Galedar, M. N., Tabatabaeefar, A., Jafari, A., Sharifi, A., Mohtasebi, S. S., \& Fadaei, H. (2010). Moisture dependent geometric and mechanical properties of wild pistachio (Pistacia vera L.) nut and kernel. International Journal of Food Properties, 13(6), 1323-1338. http://dx.doi.org/10.1080/10942910903062099

Garnayak, D. K., Pradhan, R. C., Naik, S. N., \& Bhatnagar, N. (2008). Moisture-dependent physical properties of Jatropha seed (Jatropha curcas L.). Indian J. Crops. Products., 27, 123-129. http://dx.doi.org/10.1016/j.indcrop.2007.09.001

Irtwange, S. V. (2000). The effect of accession on some physical and engineering properties of African yam bean. Unpublished Ph. D. Thesis, Department of Agricultural Engineering, University of Ibadan, Nigeria.

Joshi, D. C., Das, S. K., \& Mukherejee, R. K. (1993). Physical properties of Pumpkin seeds. J. Agr. Eng. Res., 54, 219-229. http://dx.doi.org/10.1006/jaer.1993.1016

Kingsly, A. R. P., Singh, D. B., Manikantan, M. R., \& Jain, R. K. (2006). Moisture dependent physical properties of dried pomegranate seeds (Anardana). J. Food Eng., 75, 492-496. http://dx.doi.org/10.1016/j.jfoodeng.2005.04.033

Mohsenin, N. N. (1970). Physical Properties of Plant and Animal Materials. Gordon and Breach Science Publishers, New York.

Mohsenin, N. N. (1978). Physical Properties of Plant and Animal Materials: Structures, Physical Characteristics and Mechanical Properties(1st ed.), Gordon and Breach Science Publishers, New York, USA.

Muhammad, N. O., Bamishaiye, E. I., Bamishaiye, O. M., Usman, L. A., Salawu, M. O., Nafiu, M. O., \& Oloyede, O. B. (2011). Physicochemical Properties and Fatty Acid Composition of Cyperus esculentus (Tiger Nut) Tuber Oil. Bioresearch Bulletin, 5, 51-54. 
Nikoobin, M., Mirdavardoost, F., Kashaninejad, M., \& Soltani, A. (2009). Moisture-Dependent Physical Properties of Chickpea Seeds. Journal of Food Process Engineering, 32(4), 544-564. http://dx.doi.org/10.1111/j.1745-4530.2007.00231.x

Okafor, J. N. C., Mordi, J. I., Ozuma, A. U., Solomon, H. M., \& Olatunji, O. (2003). Preliminary studies on the characteristics of contaminants in tigernuts (Yellow variety). Proceeding of the 27th Annual Nigeria Institute of Food Science and Technology (NIFST) conference, 13-17 October 2003, pp. 210-211.

Osagie, A. U., \& Eka, S.A. (1998). Lipid from plant source, structure and distribution. Proc.1st Agric Conf. on Biochemistry of lipids, 103, 21-26.

Pradhan, R. C., Naik, S. N., Bhatnagar, N., \& Swain, S. K. (2008). Moisture-dependent physical properties of Karanja (Pongamia pinnata) kernel. Ind. Crops. Products., 28(2), 155-161. http://dx.doi.org/10.1016/j.indcrop.2008.02.006

Sacilik, K., Ozturk, R., \& Keskin, R. (2003). Some physical properties of hemp seed. Biosyst. Eng., 86(2), 191-198. http://dx.doi.org/10.1016/S1537-5110(03)00130-2

Shaker, M. A., Ahmed, M. G., Amany, M. B., \& Shereen, L. N. (2009). Chufa Tubers (Cyperus esculentus L.) As a New Source of Food. World Appl. Sci. J., 2, 151-156.

Singh, K. K., \& Goswami, T. K. (1996). Physical properties of Cumin seed. J. Agric. Eng. Res., 64, 93-98. http://dx.doi.org/10.1006/jaer.1996.0049

Sreenarayanan, V. V., Subramanian, V., \& Visvanathan, R. (1985). Physical and thermal properties of soybean. Proc. Indian Soc. Agric. Eng., 3, 161-169.

Suthar, S. H., \& Das, S. K. (1996). Some physical properties of karingda [Citrullus lanatus (thumb) mansf] seeds. J. Agric. Eng. Res, 65(1), 15-22. http://dx.doi.org/10.1006/jaer.1996.0075

Tabatabeefar, A. (2003). Moisture-dependent physical properties of wheat. Int. Agrophysics, 17, 207-211.

Tavakoli, H., Rajabipour, A., \& Mohtasebi, S. S. (2009). Some Moisture-Dependent Engineering Properties of Soybean Grains. Agricultural Engineering International: the CIGR Ejournal, 6, 14.

Varnamkhasti, M. G., Mobli, H., Jafari, A., Keyhani, A. R., Soltanabadi, M. H., Rafiee, S., \& Kheiralipour, K. (2008). Some physical properties of rough rice (Oryza Sativa L.) grain. Journal of Cereal Science, 47(3), 496-501. http://dx.doi.org/10.1016/j.jcs.2007.05.014

Visvanathan, R., Palanisamy, P. T., Gothandapani, L., \& Sreenarayanan, V. V. (1996). Physical properties of Neem nut. J. Agric. Eng. Res., 63, 19-25. http://dx.doi.org/10.1006/jaer.1996.0003

\section{Copyrights}

Copyright for this article is retained by the author(s), with first publication rights granted to the journal.

This is an open-access article distributed under the terms and conditions of the Creative Commons Attribution license (http://creativecommons.org/licenses/by/3.0/). 